\title{
NDVI Predicts Birth Seasonality in Historical Baja California Sur, Mexico
}

\author{
Shane Macfarlan ${ }^{1}$, Ryan Schacht ${ }^{2}$, Izabella Bourland ${ }^{1}$, Savannah Kapp ${ }^{1}$, Trevor Glad ${ }^{1}$, \\ Lauren Lewis ${ }^{1}$, Nathan Darmiento ${ }^{1}$, Tanner Clegg ${ }^{1}$, Cole Thorpe ${ }^{1}$, Taylor Peppelar ${ }^{1}$, \\ Melissa Santiago ${ }^{2}$, Celeste Henrickson ${ }^{1}$, and Kenneth Vernon ${ }^{1}$ \\ ${ }^{1}$ University of Utah \\ ${ }^{2}$ East Carolina University
}

July 20, 2020

\begin{abstract}
Birth seasonality is a phenomenon whereby populations can be characterized by a single month or season in which births peak. While non-human animal research suggests seasonal birth-pulses are related to variation in climate and local energy availability, social scientists debate the mechanisms responsible for it in humans. Here we investigate the role of precipitation, temperature, and energy availability on seasonal birth pulses using a historical dataset from the Baja California peninsula - a hot, arid desert that experiences seasonal fluctuations in temperature, precipitation, and energy associated with the North American Monsoonal. Analyses suggest that local energy availability (as measured through NDVI) predicts seasonal birth pulses, while temperature and precipitation do not; however, both are indirectly related to it through their direct effects on NDVI. Our analyses demonstrate the importance of local energy availability on human reproductive timing and suggest that human birth seasonality is a form of traditional ecological knowledge.
\end{abstract}

TITLE: NDVI Predicts Birth Seasonality in Historical Baja California Sur, Mexico

AUTHORS: Shane J Macfarlan ${ }^{1,2,3}$ (shane.macfarlan@anthro.utah.edu), $\quad$ Ryan Schacht ${ }^{4}$ (schachtr18@ecu.edu), $\quad$ Izabella Bourland ${ }^{1,5}$ (izabella.bourland@utah.edu), $\quad$ Savannah Kapp ${ }^{1}$ (savannah.kapp@utah.edu), Trevor $\quad$ Glad $^{6}($ u0960974@utah.edu), Lauren Lewis $^{1}$ (lewis.lauren.abbey@utah.edu), Nathan Darmiento ${ }^{2,7}(\mathrm{u} 0892197 @ u t a h . e d u), \quad$ Tanner Clegg ${ }^{8}$ (tannernoahclegg@gmail.com), Cole Thorpe ${ }^{2,10}$ (colethorpe96@gmail.com), Taylor Peppelar ${ }^{1}$ (taypep@gmail.com), Melissa Santiago ${ }^{4}$ (santiagom15@ecu.edu), Celeste Henrickson ${ }^{1,11}$ (celestehenrickson@gmail.com), Kenneth Blake Vernon ${ }^{1}$ (kenneth.b.vernon@utah.edu)

${ }^{1}$ Department of Anthropology, University of Utah, Salt Lake City, UT 84112

${ }^{2}$ Center for Latin American Studies, University of Utah, Salt Lake City, UT 84112

${ }^{3}$ Global Change and Sustainability Center, University of Utah, Salt Lake City, UT 84112

${ }^{4}$ Department of Anthropology, East Carolina University, Greenville, NC 27858

${ }^{5}$ Environmental and Sustainability Studies, University of Utah, Salt Lake City, UT 84112

${ }^{6}$ Department of Music, University of Utah, Salt Lake City, UT 84112

${ }^{7}$ Department of History, University of Utah, Salt Lake City, UT 84112

${ }^{8}$ College of Humanities, University of Utah, Salt Lake City, UT 84112 
${ }^{10}$ Department of Linguistics, University of Utah, Salt Lake City, UT 84112

11 General Education, Nightingale College, Salt Lake City, UT 84111

Short Title: NDVI Predicts Birth Seasonality

Keywords: Birth Seasonality; NDVI; Baja California Sur; Mexico; Behavioral Ecology; Adaptive Strategies; Historical Demography; Mexican History

Article Type: Letters

Abstract Word Count: 150

Text Word Count: 3316

Number of References: 81

Number of Figures: 1

Number of Tables: 3

Corresponding Author:

Shane Macfarlan, 260 Central Campus Drive, Department of Anthropology, University of Utah, Salt Lake City, UT 84112

Email: shane.macfarlan@anthro.utah.edu Office Phone: (801) 587-3432

SJM conceived of the study and performed all the analyses. SJM, IB, SK, TG, LL, ND, TC, CT, TP, MS, $\mathrm{CH}, \mathrm{KBV}$ collected the data. SJM and RS wrote the first draft of the manuscript.

\section{ABSTRACT}

Birth seasonality is a phenomenon whereby populations can be characterized by a single month or season in which births peak. While non-human animal research suggests seasonal birth-pulses are related to variation in climate and local energy availability, social scientists debate the mechanisms responsible for it in humans. Here we investigate the role of precipitation, temperature, and energy availability on seasonal birth pulses using a historical dataset from the Baja California peninsula - a hot, arid desert that experiences seasonal fluctuations in temperature, precipitation, and energy associated with the North American Monsoonal. Analyses suggest that local energy availability (as measured through NDVI) predicts seasonal birth pulses, while temperature and precipitation do not; however, both are indirectly related to it through their direct effects on NDVI. Our analyses demonstrate the importance of local energy availability on human reproductive timing and suggest that human birth seasonality is a form of traditional ecological knowledge.

\section{INTRODUCTION}

Birth seasonality [one aspect of breeding phenology (Forchhammer et al. 1998; Sinclair et al. 2001)] is a common trait among many viviparous species whereby parturition events peak in a single season or month (Ellison et al. 2005; Wittemyer et al. 2007; Martinez-Bakker et al. 2014). Birth seasonality is particularly common among iteroparous organisms (those that reproduce more than once during their lifetime) residing in seasonal habitats (Pettorelli 2013). Comparative research in animal ethnology and evolutionary ecology indicate that breeding phenology is strongly associated with both climate and temporal variation in food availability across animal taxa (Drent \& Daan 1980; Kennish 1997; Forchhammer et al. 1998 ; Sinclair et al. 2001; Rubenstein \& Wikelski 2003; Wittemyer et al. 2007; Pettorelli 2013; Drake \& Martin 2018). There are clear payoffs for organisms to synchronize reproduction with local energy availability, especially among mammals with obligate pre- and post-natal parental investment (e.g. gestation, lactation, and resource provisioning) - offspring born during peaks in energy availability are heavier and have higher survival rates than those born before or after those peaks (Pettorelli 2013; Plard et al. 2014). 
Seasonal birth pulses are not unique to non-human animals and were first identified in humans nearly 200 years ago through early epidemiological research (Villerme 1831). However, despite being recognized as a near universal feature of human populations today (Cowgill 1965; Bronson 1995; Ellison et al. 2005; Dahlberg \& Andersson 2019), social scientists continue debate the mechanisms responsible for this patterning (Condon \& Scaglion 1982; Bobak and Gjonca 2001; Ellis et al. 2005; Herteliu et al. 2015; Dahlberg \& Andersson 2018, 2019). While some have favored non-adaptive socio-cultural explanations for single case studies (see review in Ellis et al. 2005), recent large-scale, cross-national datasets suggest that human birth seasonality may be related to seasonal variation in local energy availability (Martinez-Bakker et al. 2014). For example, across the northern hemisphere, human birth seasonality has a latitudinal gradient, with populations residing between the equator and 30 degrees North Latitude typically peaking in births between the fall and early winter (i.e., September through December) and those between 30 degrees North Latitude and the Arctic peaking between the spring and summer (i.e., April through August) (Martinez-Bakker 2014). The patterning of latitudinal distribution of seasonal birth pulses generally tracks ecosystem-level energy availability, which has similar seasonal variation based on a latitudinal gradient (Becker \& Boyd 1957; Lindsey 2009). Mothers who give birth during peaks in seasonal local energy availability have children with higher birth weights, larger head circumferences, and greater gestational ages, all of which are indicators of child health and survivorship (Dadvand et al. 2012; Case et al. 2016; Bakhtsiyarava et al. 2018).

Local energy availability is impacted by a number of bio-physical factors, including temperature and precipitation (Wu et al. 2001; Pettorelli 2013; Yan et al. 2015; Gilbert 2019). Not surprisingly, a large body of research has linked seasonal variation in precipitation and temperature to birth seasonality in humans (Condon \& Scaglion 1982; Lam \& Miron 1998; Ellis et al. 2005; Lawlor et al. 2005; Torche \& Corvalan 2010; Osei et al. 2016). However, these aspects of climate serve as proxy variables for local energy availability (Pettorelli 2013) and no one has examined the direct impact of local energy availability on human birth seasonality.

Accordingly, here we investigate the role of all three (precipitation, temperature, and energy availability) on monthly birth pulses in a $19^{\text {th }}$ century dataset from Baja California Sur, Mexico. Performing this research on a historical, rather than modern, dataset has several advantages. First, as global populations have become increasingly industrialized, societies have generally become reliant on infrastructure that smooths out localized environmental variability and consequent resource scarcity (e.g. drought). Hence, this reduces variability in local energy availability thereby lowering the incidence of monthly birth pulses (Dahlberg \& Andersson 2018, 2019). Conversely, subsistence-level populations are more likely to be impacted by seasonal variability in local bio-physical processes (Moran 2018). Second, as human populations continue to undergo demographic transition (i.e., lower fertility), the ability to detect birth seasonality is diminished (Dahlberg \& Andersson 2018). Historical datasets cover time periods that typically promoted early female reproduction and higher fertility (Kaplan 2006; Kaplan et al. 2000, 2001; Galor 2012; Macfarlan et al. 2019). Consequently, research on these data allow for more reliable tests of birth seasonality than among modern populations with lower fertility due to widespread contraception, public education, and the advent of scientific medicine.

\section{MATERIALS AND METHODS}

Study Site: Baja California Sur (hereafter, BCS) is one of two Mexican states that comprises the Baja California Peninsula (Krutch 1986) (Figure 1). Climatologically much of BCS is characterized as a hot, arid desert (Köppen-Geiger BWh) (Rebman \& Roberts 2012); however, portions of the southern tip of the peninsula, known as the "Cape Region", is characterized as hot and semi-arid (Köppen-Geiger BSh) (Rebman \& Roberts 2012; Flores-Cárdenas et al. 2018; Maldonado-Enriquez et al. 2020). Both regions are subject to the North American monsoon (Barron et al. 2012), a climatological phenomenon whereby an onshore wind shift occurs between July and September that is associated with an increase in temperature and precipitation (Hasting \& Turner 1965; Diaz et al. 2001; Rebman \& Roberts 2012; Barron et al. 2012). This climatological system has been estimated present for the last 7500 years (Barron et al. 2012). Directly following the monsoonal rain season, biological energy availability increases, resulting in a September through 
December growing season (Maldonado-Enriquez et al. 2020). Minor rain events continue through January; however, between March and June, life becomes increasingly difficult as precipitation virtually vanishes and temperatures rise (Salinas Zavala et al. 1990. Numerous historical accounts attest to the difficulty of surviving this arid ecosystem (Clavigero 1937; Baegert 1952).

Figure 1 approximately here

Population History: The Baja California peninsula has been inhabited by indigenous peoples for at least the last 12,000 years (Fujita; Des Lauries et al. 2015; Macfarlan \& Henrickson 2010); however, peoples of Euro-American descent began to permanently occupy the region after the Jesuits founded mission Loreto in 1697 AD (Martinez 1960; Crosby 1994). The Jesuits brought with them soldiers and their families who performed a number of economic roles to assist with the mission building process such as smithing, farming, and herding. The descendants of these initial colonists make up a portion of the peninsular population today (Martinez 1960, 1965; Crosby 1981, 1994). After 70 years of tight administrative control, the Jesuits were expelled from the Spanish Kingdom (1768 AD) and the Baja California peninsula was opened to those seeking to settle the land, resulting in a second population influx (Martinez 1960). Two additional waves of in-migration later occurred; one following Mexican Independence (1821 AD) and another that occurred throughout the Presidency of Porfirio Diaz (the Porfiriato Period: 1875-1910 AD) (Trejo Barajas 1994, 2005). Across all four migratory events, the majority of people came from Sonora and Sinaloa; however, they also included people from Asia, Europe, and North and South America (Martinez 1965; Macfarlan et al. 2019).

Throughout the $19^{\text {th }}$ century, the Baja Californian economy was largely insular, with economic ventures focusing on cattle and goat ranching, crop production (largely based on Jesuit introduced species), and mining (Trejo-Barajas \& Gonzalez 2002). Indeed, herding and horticulture still predominate throughout the rural, mountainous ranching communities today (Crosby 1981). While crop production was made possible through the irrigation of desert springs (the only permanent source of surficial fresh water that exists in BCS) (de Grenade et al. 2016), ranching was (and still is) dependent on seasonal rains to provide animal fodder. Because the Baja California peninsula was poorly integrated into the larger Mexican nation-state throughout the $19^{\text {th }}$ century (Martinez 1965; Trejo-Barajas \& Gonzalez 2002), people were highly reliant on local climatic conditions and ecology for making a living (Crosby 1981).

Data: Birth records were extracted from the, Guí Familiar de Baja California: 1700-1900 (Martinez 1965). This repository represents the largest source of vital records for the Baja California peninsula prior to the first systemic, nation-wide censuses that were initiated at the beginning of the $20^{\text {th }}$ century (Platt 1998). Due to weathering and neglect over 200+ years, some of the vital records were damaged and not transcribed. However, data loss is unbiased and does not favor (or disfavor) any particular group or time period (Macfarlan et al 2020). In all, this repository represents the single best source for reconstructing demographic process on the peninsula during the $19^{\text {th }}$ century (Macfarlan et al. 2019).

A total of 9111 birth, baptismal, and registration records were extracted from ten communities spanning the modern state of BCS (Loreto, Santiago, Santa Rosalía, Mulegé, Comondú, Todos Santos, La Paz, San Jose del Cabo, San Antonio, San Ignacio) (Figure 1). Records included a variety of information including: 1) the first and last name of the individual, 2) the day, month, and year of birth, baptism, and/or registration, 3) the location where the individual was born, baptized, and/or registered, 4) parental first and last names, and $5)$ additional notes about the individual who was born. Some records included information on individuals who were baptized or registered in one location (e.g. Santa Rosalía) but were born in a different location (e.g. Todos Santos). As such, we organized the record such that they were associated with the correct birth location. When individuals were born in locations not directly associated with one of the ten identified communities, we searched for the location using a variety of published sources (e.g. Gerhard \& Guilick 1964; Secretaría de Desarrollo Social 2020; Instituto Nacional de Estadística, Geografía e Informática 2020) and placed them into the closest community. Finally, we filtered the data to include only those records where month and year of birth were available $(\mathrm{n}=8905)$.

Community-level climatological data were aggregated from Mexican National archives (Ruiz et al. 2006). The 
data are presented as monthly temperature and precipitation averages that are based on daily measurements collected from weather stations over a 41-year period spanning 1961 and 2002 in each community (Table 2). While the time frame for weather and birth data do not overlap, the modern climatological system has been stable for at least the last several hundred years, if not longer (Baegert 1952; Diaz et al. 2001; Barron et al. 2012).

Community-level energy availability data are presented as average monthly Normalized Difference Vegetation Indices (NDVI). NDVI values (which range from negative one to one) quantify the spatio-temporal variability in green biomass (i.e., vegetation) by measuring the difference between remotely sensed red and near-infrared light (which vegetation reflects and absorbs, respectively) (Hamel et al. 2009; Pettorelli 2013). Data were queried from the MODIS/VIIRS Global Subsets Tool using a 16-day interval, 250-meter resolution across a 19-year period (January 1, 2001 through December 31, 2019) (Didan 2015). For each of the ten communities, we used three square-kilometer polygons to assess intra-annual energy availability (Table 2) (ORNL DAAC 2018a,b,c,d,e,f,g,h,i,j). To account for urbanization in the communities of San Jose del Cabo and La Paz, we offset our polygons to non-developed plots immediately adjacent to the community (ORNL DAAC 2018a,e). Although the NDVI data does not overlap temporally with our birth data, and NDVI values may be lower than that observed during the historical period due to urbanization, the seasonal change in NDVI values within communities should be comparable based on the stability of the climatic regimes over the last several thousand years (Baegert 1952; Diaz et al. 2001; Barron et al. 2012).

Tables 1 and 2 approximately here

Analytic Modeling: All statistical modeling was run in STATA/IC 16.1 (StataCorp 2019) and can be replicated using the associated Stata "do file" (see Supplemental Information). To examine whether precipitation and temperature or local energy availability impact monthly birth pulses, our birth record database was transformed into a monthly birth pulse database, whereby each row represented the number of births recorded in a particular community, in a particular month, in a particular year (See Data Supplement). The outcome variable was the number of births within a month. The independent variables included average precipitation by month, average temperature by month, average NDVI score by month, and the year of birth. To deal with the fact that some communities did not have births in some months and/or years, we employ a Zero-Inflated Poisson model which accounts for those cases where no births were recorded. Because data are nested within communities, we use clustered-robust standard errors at the level of the community.

\section{RESULTS}

As an initial data check, we perform OLS regression to assess the impact of average monthly precipitation and temperature on NDVI. Because the data are nested at the level of the community, we employ clustered robust standard errors around community. We find that both climatic variables are significantly related to monthly average NDVI $\left(\mathrm{R}^{2}=0.51 ; \mathrm{p}<.001 ; \mathrm{n}\right.$-observations=120; n-groups $\left.=10\right)$, with NDVI positively associated with precipitation $(\mathrm{B}=0.003 ; \mathrm{p}<.001)$ and negatively associated with temperature $(\mathrm{B}=-0.006 ; \mathrm{p}=.002)$.

Do precipitation, temperature, and energy availability affect monthly birth pulses?

After controlling for year of birth, our analytic model shows that NDVI is significantly associated with monthly birth pulses (IRR $=15.2 ; \mathrm{p}<.001)$. In fact, for every one unit increase in NDVI the incident rate for monthly birth pulses increased by a factor of fifteen. However, neither precipitation nor temperature were associated with monthly birth pulses (Table 3 ). Consistent with population growth over time, we find that monthly birth pulses increased substantially over time $(\operatorname{IRR}=1.02 ; \mathrm{p}<.001)$.

Table 3 approximately here

\section{DISCUSSION}

Leveraging historical data, here we explored the relationship between birth seasonality and three measures of energy availability (precipitation, temperature, and NDVI) in the physically demanding, hot and arid Baja California peninsula. We find, consistent with the animal ethology and evolutionary ecology literature, 
that local energy availability evaluated by way NDVI to be positively associated with monthly birth pulses. Although a relationship between precipitation and temperature on monthly birth pulses in humans has been found in past studies (Condon \& Scaglion 1982; Lam \& Miron 1998; Lawlor et al. 2005; Torche \& Corvalan 2010; Osei et al. 2016), here we find that they have no significant effect on birth seasonality; however, both are indirectly related to it through their combined impact on NDVI.

Taken together, our findings suggest that human birth seasonality represents a locally-sensitive adaptive strategy designed to improve child health and survival outcomes and, ultimately, parental reproductive success (Ellison et al. 2005). Much of the Baja California peninsula is a hot, arid desert and, historically, people were dependent on seasonal rains for subsistence and economic livelihoods (Crosby 1981). Given our results, it appears that, at least during the $19^{\text {th }}$ century, parents timed their births to coincide with seasonal variation in local energy availability. We do not suggest that individuals necessarily maintained and followed an explicit cultural rule stating, "give birth in the Fall and Winter". Rather, we suggest that this patterning emerged by way of a form of embodied traditional ecological knowledge - that is, knowledge that is acquired and transmitted through lived experience within an ecosystem (Berkes et al. 2000). During the time period under study, economic livelihoods were nearly completely tethered to local ecology because of limited infrastructure development. Consequently, individuals were acutely aware of seasonal changes to both climate and energy availability (Crosby 1981). Thus, given similar results across animal taxa, individuals who timed their births to seasonal pulses in energy likely improved their children's survival prospects (and their own lifetime reproductive success) (Dadvand et al. 2012; Case et al. 2016; Bakhtsiyarava et al. 2018). Today, subsistence ranchers residing in mountain ranges that lack infrastructure in BCS provide anecdotal evidence regarding this phenomenon. The lead author's (SJM) conversations with women in these populations suggest that while they lack explicit cultural rules regarding the timing of birth, they unequivocally state that having a baby during the September through December growing season, makes life easier. During this time period their livestock gain weight rapidly, provide more milk and meat, and can also be sold in local markets for a better price per animal. Thus, maternal and child condition, as well as household economic wellbeing, are all improved with the advent of the rains.

In industrialized settings, however, humans are increasingly decoupled from the constraints of their local bio-physical ecology as resources are extracted and manufactured using extra-somatic energy sources (e.g., fossil fuels) and distributed through globally integrated market supply chains and (Li \& Li 2012; Moran 2018). Under these conditions, in modern, developed populations, cultural institutions that influence social, economic, and reproductive success may have a greater influence on seasonal birth pulses than local energy availability (Dahlberg \& Andersson 2018, 2019). For example, evidence from modern Japan show that births spike just after the cut-off date for school enrollment, which causes these children to be the oldest among their school cohort (Shigeoka 2014). Being oldest among an educational cohort promotes educational and economic prospects relative to those who are younger (Davis et al. 1980 Lien et al. 2005; Nolan \& Howell 2010; Verachtert et al. 2010). One goal of research in the near future is to adjudicate the relationships between birth pulses, infrastructure development, climate, and energy in BCS by examining modern birth records.

Readers should be mindful of the limitations of this study. First, the data for births emanate from the $19^{\text {th }}$ century, while our data on climate and local energy availability come from the mid- $20^{\text {th }}$ through early$21^{\text {st }}$ centuries. While temporal overlap between variables is ideal, it is impossible to obtain yearly precipitation, temperature, and NDVI data for the $19^{\text {th }}$ century at the scale of individual community. Nonetheless, paleoclimatological, historical, and ethnographic data all indicate relatively similar environmental trends between today and the $19^{\text {th }}$ century. Certainly, that we detect a relationship between seasonal pulses in NDVI and birth patterns supports our analytical approach and suggests that this association may in fact be stronger if our data were temporally matched. Second, as is typical with historical vital records, our data represent a sample of all births that occurred on the peninsula during the $19^{\text {th }}$ century. While missing data can produce biased estimates (Willigan \& Lynch 1982), there is no reason to assume that data loss in these vital records was biased in any particular direction. Lastly, the El Niño Southern Oscillation (ENSO) is a significant source of inter-annual variability for both the North American Monsoonal (Barron et al. 2012) and Baja Californian climate (Diaz et al. 2001; Lluch-Cota et al. 2010). Our analyses do not account for 
these events. During El Niño events, precipitation increases substantially increasing local energy availability, while during La Niña events they decrease (Diaz et al. 2001; Maldonado-Enriquez et al. 2020). Understanding the relationship between ENSO events, precipitation, and monthly birth pulses may shed light on additional sources of traditional ecological knowledge and methods for investigating ENSO events in the historic period. Because monthly birth pulses and NDVI are correlated and ENSO events and NDVI are correlated, it may be possible to identify historical ENSO events by examining inter-annual historical fluctuations in birth pulses, similar to how dendrochronologists use tree-ring width as a proxy for estimating historic ENSO events (Diaz et al. 2001).

In conclusion, we find that seasonal variation in local energy availability predicts birth seasonality across 10 communities in Baja California Sur, Mexico in the $19^{\text {th }}$ century. Although social scientists have alluded to the climatological factors that influence seasonal variation in female energetics driving birth seasonality in humans (Ellison et al. 2005), our analysis represents the first attempt to adjudicate between various measures of energy availability. While past work has used precipitation and temperature as proxies, here we use a more direct measure of energy availability by way of NDVI. In doing so, we clearly show that birth seasonality covaries with green biomass, which is of particular importance to the subsistence livestock producers under study here. While climatological phenomena (precipitation and temperature) were not found to have direct effects on birth seasonality, we find support for their indirect effect through NDVI. Ultimately, our work further highlights the responsiveness of individuals to the biophysical properties of local environments and insight that can be gleaned from a historical and comparative approach.

\section{ACKNOWLEDGEMENTS}

Portions of this work was financially supported through the Center for Latin American Studies and the Office for Undergraduate Research at the University of Utah.

\section{REFERENCES}

Baegert, J.J. (1952). Observations in Lower California . Translation, Introduction, and Notes by M.M. Brandenberg and C.L. Baumann. University of California Press, Berkeley, CA.

Bakhtsiyarava, M., Grace, K., \& Nawrotzki, R.J. (2018). Climate, birth weight, and agricultural livelihoods in Kenya and Mali. Am J Public Health 108, S144-S150.

Barron, J.A., Metcalfe S.E., \& Addison J.A. (2012). Response of the North American monsoon to regional changes in ocean surface temperature.Paleooceanography 27, PA3206.

Berkes, F., Colding, J., \& Folke, C. (2000). Rediscovery of traditional ecological knowledge as adaptive management. Ecol Appl10 , 1251-1262.

Bobak, M. \& Gjonca, A. (2001). The seasonality of live births is strongly influenced by socio-demographic factors. Hum Reprod16 , 1512-1517.

Bronson, F.H. (1995). Seasonal variation in human reproduction: environmental factors. Q Rev Biol 70 , 141-164.

Casey, J.A., James, P., Rudolph, K.E., Wu, C.D., \& Schwartz, B.S. (2016). Greenness and birth outcomes in a range of Pennsylvania communities. Int $J$ Env ResPub He 13, 311.

Clavigero, F.J. (1937). The History of [Lower] California . translated by Sara E. Lake and A.A. Gray. Stanford University Press, Stanford, CA.

Condon, R.G., \& Scaglion, R. (1982). The ecology of human birth seasonality. Hum Ecol 10 , 495-511.

Cowgill, U.M. (1965). Season of birth in man, contemporary situation with special reference to Europe and the Southern Hemisphere.Ecology 47 , 614-623.

Crosby, H.W. (1981). Last of the Californios . Copley Books, La Jolla, CA. 
Crosby, H.W. (1994). Antigua California: Mission and Colony on the Peninsular Frontier, 1697-1768. University of New Mexico Press, Albuquerque, NM.

Dadvand, P., Sunyer, J., Basagaña, X., Ballester, F., Lertxundi, A., Fernandez-Somoano, A., et al. (2012). Surrounding greenness and pregnancy outcomes in four Spanish birth cohorts. Environ Health Persp 129, 1481-1487.

Dahlberg, J., \& Andersson, G. (2018). Changing seasonal variation in births by sociodemographic factors: A population-based register study.Hum Reprod Open 2018(4) , hoy015.https://doi.org/10.1093/hropen/hoy015

Dahlberg, J., \& Andersson, G. (2019). Fecundity and human birth seasonality in Sweden: A register-based study. Reprod Health $\mathbf{1 6}, 87$.

Davis, B.G., Trimble, C.S., \& Vincent, D.R. (1980). Does age of entrance affect school achievement? Elem Sch J80,133-143.

de Grenade, R., G.P. Nabhan, \& M. Cariño Olvera. 2016. Oases of the Baja California peninsula as sacred spaces of agrobiodiversity persistence. Agriculture and Human Values 33:455-474.

Des Lauriers, M.R., Davis, L.G., Turnbull III, J., Southon, J.R., \&Taylor, R.E. (2017). The earliest shell fishhooks from the Americas reveal fishing technology of Pleistocene maritime foragers. Am Antiquity $\mathbf{8 2}$, 498-516.

Diaz, S.C., Touchan, R., \& Swetnam, T.W. (2001). A tree-ring reconstruction of past precipitation for Baja California Sur, Mexico.Int J Climatol 21, 1007-1019.

Didan, K. (2015). MOD13Q1 MODIS/Terra Vegetation Indices 16-Day L3 Global 250m SIN Grid V006. NASA EOSDIS Land Processes DAAC. https://doi.org/10.5067/MODIS/MOD13Q1.006

Drent, R.H., \& Daan, S. (1980). The prudent parent - energetic adjustments in avian breeding. Ardea 68 , 225-252.

Forchhammer, M.C., Post, E., \& Stenseth, N.C. (1998). Breeding phenology and climate. Nature 391 , 29-30.

Fujita, H. (1995). Prehistoric coastal adaptations in the Cape Region, Baja California Sur. Pac Coast Archaeol Soc $Q \mathbf{3 1}, 4-19$.

Galor, O. (2012). The demographic transition: Causes and consequences.Cliometrica 6 , 1-28.

Gerhard, H. E., \& Guilick, P. (1964). Lower California Guidebook: A Descriptive Traveler's Guide . The Arthur H. Clark Company, Glendale, CA.

Gilbert, J.P. (2019). Temperature directly and indirectly ifluences food web structure. Sci Rep UK 9 , 5312.

Hamel, S., Garel, M., Festa-Bianchet, M., Gailard, J.M., \& Côté, S.D. (2009). Spring Normalized Difference Vegetation Index (NDVI) predicts annual variation in timing of peak faecal crude protein in mountain ungulates. J Appl Ecol 46 , 582-589.

Hastings, J.R., \& Turner, R.M. (1965). Precipitation regimes in Baja California, Mexico. Geogr Ann A 47 , 204-223.

Herteliu, C., Ileanu, B., Ausloos, M., \& Rotundo, G. (2015). Effect of religious rules on time of conception in Romania from 1905 to 2001.Hum Reprod 30 , 2202-2214.

Instituto Nacional de Estadística, Geografía e Informática. 2020.Archivo Histórico de Localidades Geoestadísticas . Available at:https://www.inegi.org.mx/app/geo2/ahl/default.html\#Catalogos_predefinidos. Last Accessed 15, May 2020.

Kaplan, H. (1996). A theory of fertility and parental investment in traditional and modern human societies. Am J Phys Anthropol101, 91-135. 
Kaplan, H., Hill, K., Lancaster, J. \& Hurtado, A.M. (2000). Theory of human life history evolution: diet, intelligence, and longevity.Evol Anthropol 9 , 156-185.

Kaplan, H., Hill, K., Hurtado, A.M., \& Lancaster, J. (2001). The embodied capital theory of human evolution. In: Reproductive Ecology and Human Evolution, [ed. Ellison, P.T.]. Aldine Transaction, New Jersey. Pp. 293-318.

Kennish, R. (1997). Seasonal patterns of food availability: influences on the reproductive output and body condition of the herbivorous crab Grapsus albolineatus . Oecologia 109, 209-218.

Krutch, J.W. (1986). The Forgotten Peninsula: A Naturalist in Baja California . University of Arizona Press, Tucson, AZ.

Lam, D.A., \& Miron J.A. (1994) Global patterns of seasonal variation in human fertility. Ann NY Acad Sci 709, 9-28.

Lam, D.A., \& Miron J.A. (1996). The effects of temperature on human fertility. Demography 33, 291-305.

Lawlor, D.A., Leon, D.A., \& Smith, G.D. (2005). The association of ambient outdoor temperature throughout pregnancy and offspring birthweight: findings from the Aberdeen Children of the 1950scohort. Obstet Gynecol $112,647-657$.

Li, W., \& Li, Y. (2012). Managing rangeland as a complex system: How government interventions decouple social systems from ecological systems. Ecol Soc $17,9$.

Lien, L., Tambs, K., Oppedal, B., Heyeradahl, S., \& and Bjertness, E. (2005). Is relatively young age within a school year a risk factor for mental health problems and poor school performance? A population-based cross-sectional study of adolescents in Oslo, Norway. BMC Public Health 5 , 102.

Lindsey, R. (2009). Climate and Earth's energy budget. NASA Earth Observatory. Available at:https://earthobservatory.nasa.gov/features/EnergyBalance/page1.php. Last Accessed on 8 July 2020.

Lluch-Cota, S., Parés-Sierra, A., Magaña-Rueda, V.O., Arreguín-Sánchez, R., Bazzino, G., HerreraCervantes, H., \& Lluch-Belda, D. (2010). Changing climate in the Gulf of California. Prog Oceanogr 87 , 114-126.

Macfarlan, S.J., \& Henrickson, C.N. (2010) Inferring relationships between indigenous Baja California Sur and Seri/Comcáac populations through cultural traits. J Calif Gt Basin Anthropol 30 , 51-68.

Macfarlan, S.J., Schacht, R., Foley, C., Cahoon, S., Osusky, G., Vernon, K.B., et al. (2020). Marriage dynamics in old Lower California: Ecological constraints and reproductive value in an arid peninsular frontier. Biodemogr Soc Biol 65 , 156-171.

Maldonado-Enriquez, D., Ortega-Rubio, A., Breceda-Solís Cámara, A.M., Díaz-Castro, S.C., Sosa-Ramírez, J., \& Martínez-Rincón, R.O. (2020). Trend and variability of NDVI of the main vegetation types in the Cape Region of Baja California Sur. Rev Mex Biodivers 91, e913213.

Martinez, P.L. (1960). A History of Lower California . Trans. E. D. Turner. Editorial Baja California, La Paz, BCS.

Martinez, P.L. (1965). Guía Familiar de Baja California: 1700-1900 . Instituto Sudcaliforniano de Cultural, La Paz, BCS.

Moran, E. (2018). Human Adaptability: An Introduction to Ecological Anthropology . $3^{\text {rd }}$ Edition. Routledge, New York, NY.

Nolan, J.E., \& Howell, G. (2010). Hockey success and birth date: The relative age effect revisited. Int Rev Sociol Sport 45, 507-512. 
Plard, F., Gaillard, J.M., Coulson, T., Hewison, A.J.M., Delorme, D., Warnant, C., \& Bonenfant, C. (2014). Mismatch between birth date and vegetation phenology slows the demography of Roe Deer. PLoS Biol12 , e1001828.

Platt, L.D. (1998). Census Records for Latin America and the Hispanic United States . Genealogic Publishing Company, Baltimore, MD.

Rebman, J.P., \& Roberts, N.C. (2012). Baja California Plant Field Guide . $3^{\text {rd }}$ Ed. Sunbelt Publication, San Diego, CA.

Rubenstein, D.R., \& Wikelski, M. (2003). Seasonal changes in food quality: a proximate cue for reproductive timing in marine iguanas.Ecology 84, 3013-3203.

Ruiz, J.A., Diaz, G., Reza, R., Serrano, V., \& Medina, G. (2006).Estadisticas climatológicas básicas del estado de Baja California Sur (Período 1961-2003) . Libro Técnico Núm. 2. INIFAP-CIRNO: Ciudad Obregon, Sonora, México.

ORNL DAAC. (2018a). MODIS and VIIRS Land Products Global Subsetting and Visualization Tool. ORNL DAAC, Oak Ridge, Tennessee, USA. Accessed July 10, 2020. Subset obtained for MOD13Q1 product at $23.072 \mathrm{~N}, 109.74 \mathrm{~W}$, time period: $2001-01-01$ to $2019-12-31$, and subset size: $6.25 \mathrm{x} 6.25 \mathrm{~km}$. https://doi.org/10.3334/ORNLDAAC/1379

ORNL DAAC. (2018b). MODIS and VIIRS Land Products Global Subsetting and Visualization Tool. ORNL DAAC, Oak Ridge, Tennessee, USA. Accessed July 10, 2020. Subset obtained for MOD13Q1 product at $23.4495 \mathrm{~N}, 110.2261 \mathrm{~W}$, time period: $2001-01-01$ to $2019-12-31$, and subset size: $6.25 \times 6.25 \mathrm{~km}$. https://doi.org/10.3334/ORNLDAAC/1379

ORNL DAAC. (2018c). MODIS and VIIRS Land Products Global Subsetting and Visualization Tool. ORNL DAAC, Oak Ridge, Tennessee, USA. Accessed July 10, 2020. Subset obtained for MOD13Q1 product at $23.8098 \mathrm{~N}, 110.057 \mathrm{~W}$, time period: $2001-01-01$ to $2019-12-31$, and subset size: $6.25 \times 6.25 \mathrm{~km}$. https://doi.org/10.3334/ORNLDAAC/1379

ORNL DAAC. (2018d). MODIS and VIIRS Land Products Global Subsetting and Visualization Tool. ORNL DAAC, Oak Ridge, Tennessee, USA. Accessed July 10, 2020. Subset obtained for MOD13Q1 product at $23.4794 \mathrm{~N}, 109.7189 \mathrm{~W}$, time period: $2001-01-01$ to $2019-12-31$, and subset size: $6.25 \times 6.25 \mathrm{~km}$. https://doi.org/10.3334/ORNLDAAC/1379

ORNL DAAC. (2018e). MODIS and VIIRS Land Products Global Subsetting and Visualization Tool. ORNL DAAC, Oak Ridge, Tennessee, USA. Accessed July 10, 2020. Subset obtained for MOD13Q1 product at $24.14 \mathrm{~N}, 110.46 \mathrm{~W}$, time period: $2001-01-01$ to $2019-12-31$, and subset size: $6.25 \times 6.25 \mathrm{~km}$. https://doi.org/10.3334/ORNLDAAC/1379

ORNL DAAC. (2018f). MODIS and VIIRS Land Products Global Subsetting and Visualization Tool. ORNL DAAC, Oak Ridge, Tennessee, USA. Accessed July 10, 2020. Subset obtained for MOD13Q1 product at $26.0152 \mathrm{~N}, 111.363 \mathrm{~W}$, time period: $2001-01-01$ to $2019-12-31$, and subset size: $6.25 \times 6.25 \mathrm{~km}$. https://doi.org/10.3334/ORNLDAAC/1379

ORNL DAAC. (2018g). MODIS and VIIRS Land Products Global Subsetting and Visualization Tool. ORNL DAAC, Oak Ridge, Tennessee, USA. Accessed July 10, 2020. Subset obtained for MOD13Q1 product at $26.0593 \mathrm{~N}, 111.8232 \mathrm{~W}$, time period: $2001-01-01$ to $2019-12-31$, and subset size: $6.25 \times 6.25 \mathrm{~km}$. https://doi.org/10.3334/ORNLDAAC/1379

ORNL DAAC. (2018h). MODIS and VIIRS Land Products Global Subsetting and Visualization Tool. ORNL DAAC, Oak Ridge, Tennessee, USA. Accessed July 10, 2020. Subset obtained for MOD13Q1 product at $26.8899 \mathrm{~N}, 111.983 \mathrm{~W}$, time period: $2001-01-01$ to $2019-12-31$, and subset size: $6.25 \times 6.25 \mathrm{~km}$. https://doi.org/10.3334/ORNLDAAC/1379 
ORNL DAAC. (2018i). MODIS and VIIRS Land Products Global Subsetting and Visualization Tool. ORNL DAAC, Oak Ridge, Tennessee, USA. Accessed July 10, 2020. Subset obtained for MOD13Q1 product at $27.283 \mathrm{~N}, 112.8967 \mathrm{~W}$, time period: $2001-01-01$ to $2019-12-31$, and subset size: $6.25 \times 6.25 \mathrm{~km}$. https://doi.org/10.3334/ORNLDAAC/1379

ORNL DAAC. (2018j). MODIS and VIIRS Land Products Global Subsetting and Visualization Tool. ORNL DAAC, Oak Ridge, Tennessee, USA. Accessed July 10, 2020. Subset obtained for MOD13Q1 product at $27.337 \mathrm{~N}, 112.284 \mathrm{~W}$, time period: $2001-01-01$ to $2019-12-31$, and subset size: $6.25 \times 6.25 \mathrm{~km}$. https://doi.org/10.3334/ORNLDAAC/1379

Osei, E., Agbemefle, I., Kye-Duodu, G., Binka, F.N. (2016). Linear trends and seasonality of births and perinatal outcomes in Upper East Region, Ghana from 2010-2014. BMC Pregnancy and Childb16 , 48.

Pettorelli, N. The Normalized Difference Vegetation Index . Oxford University Press, Oxford, UK.

Salinas Zavala, C. A., Leyva Contreras, A., Lluch Belda, D., \& Diaz Rivera, E. (1990). Distribución geográfica y variabilidad climática de los regimens pluciomeétricos en Baja California Sur, México.Atmosfera 3 , 217237.

Secretaría de Desarrollo Social. (2020). Catálogo de Localidades. Available at: http://www.microrregiones.gob.mx/catloc/Default.aspx?tipo=clave\&campo=mun\&valor=03. Last $\quad$ Accessed 15 May 2020.

Shigeoka, H. (2014). School entry cutoff date and the timing of births. NBER Working Paper No. 21402 NBER. Available at SSRN: http://dx.doi.org/10.2139/ssrn.2297711.

Sinclair, A.R.E. (2000). What determines phenology and synchrony of ungulate breeding in Serengeti? Ecology 81, 2100-2111.

StataCorp. (2019). Stata Statistical Software: Release 16 . StataCorp LLC, College Station, TX.

Torche, F., \& Corvalan, A. (2010) Seasonality of birth weight in Chile: Environmental and socioeconomic factors. Ann Epidemiol20 , 818-826.

Trejo Barajas, D. (1994). La Población de La California peninsular en el siglo XIX. In Población y Grupos de Poder en La Península de Baja California, [ed. Trejo Barajas D \& Landavazo Arias, M.A.]. Universidad Autónoma de Baja California Sur, La Paz, BCS, Mexico. pp. 14-69

Trejo Barajas, D. (2005). Declinación y crecimiento demográfico en baja California, siglos XVIII y XIX. Una perspectiva desde los censos y padrones locales. Hist Mexicana 54,761-831.

Trejo Barajas, D., \& González Cruz, E. (2002). Historia General de Baja California Sur: I. La Economía Regional . Universidad Autónoma de Baja California Sur, La Paz, BCS, Mexico.

Verachtert, P., De Fraine, B., Onghena, P., \& Ghesquiere, P. (2010). Season of birth and school success in the early years of primary education. Oxford Rev Edu 36 , 285-306.

Villerme, P. (1831). De la distribution par mois des conceptions.Ann. Hyg. Publ. Industr. Soc. 5 , 55-155.

Willigan, J.D., \& Lynch, K.A. (1982). Sources and Methods of Historical Demography . Academic Press, New York.

Wittemyer, G., Rasmussen, H.B., \& Douglas-Hamilton, I. (2007). Breeding phenology in relation to NDVI variability in free-ranging African elephants. Ecography 31, 42-50.

Wu, Z., Dijkstra, P., Koch, G.W., Penuelas, J., \& Hungate, B.A. (2011). Responses of terrestrial ecosystems to temperature and precipitation change: a meta-analysis of experimental manipulation. Glob Change Biol $17,927-942$. 
Yan, H., Liang, C., Li, Z. Liu, Z., Miao, B., He, C., \& Sheng, L. (2015). Impact of precipitation patterns on biomass and species richness of annuals in a dry steppe. PLoS One 10, e0125300.

Figure 1. Map of Baja California Sur and the ten communities identified in the text.

Table 1. Descriptive statistics associated birth records by community, organized by number of records in descending order.

\begin{tabular}{llllll}
\hline Community & \# Records & \# Records with Month/Year Info & \# Years with Data & Years Covered & Records Per \\
\hline San Jose del Cabo* & 2381 & 2369 & 80 & $1815-1900$ & 29.6 \\
San Antonio* & 2195 & 2036 & 72 & $1809-1886$ & 28.3 \\
Todos Santos & 1332 & 1321 & 67 & $1823-1900$ & 19.7 \\
Comondu* & 942 & 938 & 52 & $1768-1900$ & 18.0 \\
La Paz* & 903 & 890 & 60 & $1829-1900$ & 14.8 \\
Santiago* & 544 & 542 & 50 & $1823-1900$ & 10.8 \\
Santa Rosalia* & 301 & 301 & 25 & $1872-1900$ & 12.0 \\
Mulegé* & 224 & 221 & 13 & $1874-1888$ & 17.0 \\
Loreto* & 192 & 190 & 22 & $1871-1897$ & 8.6 \\
San Ignacio* & 97 & 97 & 12 & $1866-1888$ & 8.1 \\
\hline
\end{tabular}

* The data for these communities include non-consecutive years.

Table 2. Mean Temperature, precipitation, NDVI, and births per month by community and month, organized by Latitude in descending order. Highest average values are in bold.

\begin{tabular}{llll}
\hline & Jan & Feb & Mar \\
\hline Mean Temperature (C) & Mean Temperature (C) & Mean Temperature (C) & Mean Temperature (C) \\
Santa Rosalía & 16.4 & 17.3 & 19 \\
San Ignacio & 15.9 & 16.6 & 18 \\
Mulegé & 13.8 & 15.4 & 16.9 \\
Comondú & 17.4 & 18.2 & 18.9 \\
Loreto & 17 & 17.6 & 18.9 \\
La Paz & 16.8 & 17.7 & 19.2 \\
San Antonio & 16.5 & 17.6 & 19.4 \\
Santiago & 16.8 & 17.5 & 19.3 \\
Todos Santos & 18.2 & 18 & 17.9 \\
San Jose del Cabo & 18.3 & 18.5 & 19.5 \\
Mean Precipitation (mm) & Mean Precipitation (mm) & Mean Precipitation (mm) & Mean Precipitation (mm) \\
Santa Rosalía & 10.4 & 6.1 & 1.3 \\
San Ignacio & 10.9 & 8.4 & 4.3 \\
Mulegé & 14.3 & 5.3 & 1.7 \\
Comondú & 20.4 & 23.3 & 5.5 \\
Loreto & 14.5 & 5.4 & 1.2 \\
La Paz & 14.8 & 5.3 & 2.3 \\
San Antonio & 6.6 & 2.7 \\
Santiago & 17.5 & 3.8 & 1.4 \\
Todos Santos & 14.3 & 7.3 & 2 \\
San Jose del Cabo & 16.2 & 4.6 & 1.5 \\
Mean NDVI & 16.6 & Mean NDVI & Mean NDVI \\
Santa Rosalía & Mean NDVI & 0.17 & 0.15 \\
San Ignacio & 0.18 & 0.22 & 0.20 \\
& 0.23 & &
\end{tabular}




\begin{tabular}{llll}
\hline & Jan & Feb & Mar \\
\hline Mulegé & 0.25 & 0.22 & 0.19 \\
Comondú & 0.26 & 0.24 & 0.22 \\
Loreto & 0.26 & 0.24 & 0.22 \\
La Paz & 0.23 & 0.21 & 0.19 \\
San Antonio & 0.40 & 0.34 & 0.28 \\
Santiago & 0.33 & 0.29 & 0.26 \\
Todos Santos & 0.28 & 0.27 & 0.25 \\
San Jose del Cabo & 0.35 & 0.30 & 0.26 \\
Mean \# of Births per Month & Mean \# of Births per Month & Mean \# of Births per Month & Mean \# of Births per Mont \\
Santa Rosalía & 0.9 & 0.8 & 1.1 \\
San Ignacio & 0.3 & 1.5 & 0.5 \\
Mulegé & 1.2 & 1.3 & 2 \\
Comondú & 1.7 & $\mathbf{2 . 1}$ & 1.9 \\
Loreto & 0.6 & 0.5 & 0.4 \\
La Paz & 1.5 & 1.3 & 1.4 \\
San Antonio & 2.8 & 2.6 & 2.5 \\
Santiago & 0.8 & 0.8 \\
Todos Santos & 0.8 & 1.9 & 1.5 \\
San Jose del Cabo & 2 & 2.6 & 2.8 \\
\hline
\end{tabular}

Table 3. Zero-Inflated Poisson Regression coefficient model ${ }^{*}$ explaining monthly birth pulses

\begin{tabular}{llll}
\hline & IRR(RSE) & Z & P \\
\hline NDVI & $15.2(5.2)$ & 7.9 & $<.001$ \\
Year & $1.02(0.002)$ & 7.5 & $<.001$ \\
Precipitation & $0.99(0.001)$ & -1.8 & .08 \\
Temperature & $0.98(0.006)$ & -1.8 & .08 \\
Constant & $2.62 \mathrm{e}-14(1.1 \mathrm{e}-13)$ & -7.4 & $<.001$ \\
Inflation Constant & $-1.12(0.3)$ & -3.6 & $<.001$ \\
\hline
\end{tabular}

${ }^{*}$ Wald $\mathrm{X} 2=206 ; \mathrm{p}<.001 ; \mathrm{n}=5451$; zero observations $=2051$; non-zero observations $=3400$

+ IRR(RSE): Incident Rate Ratio (Robust Standard Error) 


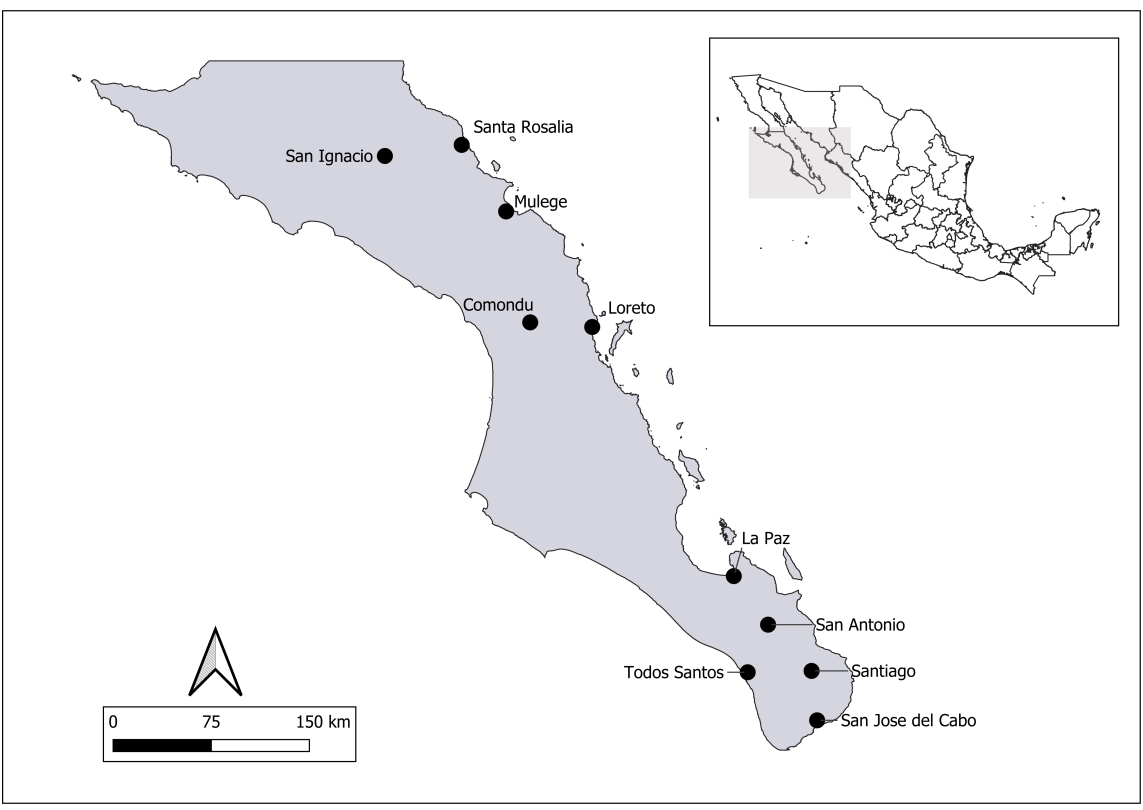

